\title{
In situ measurements of till deformation and water pressure
}

\author{
Martin TRUFFER, William D. HARRISON \\ Geophysical Institute, University of Alaska Fairbanks, 903 Koyukuk Drive, Fairbanks, Alaska 99775-7320, USA \\ E-mail: truffer@gi.alaska.edu
}

\begin{abstract}
A newly developed hammer was used to insert two autonomous probes $0.8 \mathrm{~m}$ and $2.1 \mathrm{~m}$ into clast-rich subglacial till under Black Rapids Glacier, Alaska, USA. Both probes were instrumented with a dual-axis tilt sensor and a pore-water pressure transducer. The data are compared to a $\mathbf{7 5}$ day record of surface velocities. Till deformation at depth was found to be highly seasonal: it is significant during an early-season speed-up event, but during long periods thereafter measured till deformation rates are negligible. Both tilt records show rotation around the probe axis, which indicates a change in tilt direction of about $30^{\circ}$. The tilt records are very similar, suggesting spatial homogeneity on the scale of the probe separation ( $4 \mathrm{~m}$ horizontal and $3.3 \mathrm{~m}$ vertical). There is evidence that during much of the year sliding of ice over till or deformation of a thin till layer $(<20 \mathrm{~cm})$ accounts for at least two-thirds of total basal motion. Basal motion accounts for $50-70 \%$ of the total surface motion. The inferred amount of ice-till sliding is larger than that found at the same location in a previous study, when surface velocities were about $10 \%$ lower. We suggest that variations in ice-till coupling account for the observed variations in mean annual speed.
\end{abstract}

\section{INTRODUCTION}

\section{Measurements of basal motion}

A large fraction of a temperate glacier's motion may occur at or near the base. Possible mechanisms include enhanced deformation of basal ice around bed irregularities, regelation of ice around small bed irregularities, sliding of ice over the ice-bed interface, deformation of subglacial till (including faulting) and sliding of till over bedrock. It is conceivable (or even likely) that more than one of these mechanisms operates simultaneously.

Basal motion has been investigated theoretically, in field studies (borehole, natural cavity and tunnel experiments) and in laboratory studies. It has long been clear that basal motion and subglacial hydraulics are highly interdependent. For the case of ice flowing over hard bedrock, this has been addressed theoretically (Kamb, 1987). There is no similar theory for water drainage and basal motion for soft or mixed beds.

Laboratory studies of till have focused on the highly nonlinear till rheology. They have demonstrated that relatively small samples of a till matrix deform according to a Coulomb failure criterion with a critical stress that depends linearly on effective pressure (e.g. Iverson and others, 1998). They have not, however, addressed the role of large clasts or the question of coupling between ice and till.

Iverson and others (2003) used a tunnel underneath Engabreen, Norway, for a controlled in situ experiment of till deformation. Their results suggest that the coupling of ice to till is a function of water pressure. As water pressure increases, basal ice becomes decoupled from the underlying till; this increases sliding, but reduces till deformation. With decreasing water pressure the ice-till coupling increases again, and till deformation becomes more significant. This has also been found in borehole studies, using tiltmeters (Iverson and others, 1995) and ploughmeters (Fischer and others, 1999). Ice-till decoupling can lead to an elastic reaction of the till (Fischer and Clarke, 2001) or to squeezing of sediment into the created void (Iverson and others, 1995). Both processes affect tiltmeters embedded in subglacial till.
Iverson (1999), Tulaczyk (1999) and Thorsteinsson and Raymond (2000) present theoretical treatments of ice-till coupling. Clasts that are partially embedded in ice and plough through the substrate play an important role, as does the till granularity. In the case of the relatively shallow (low driving stress) Ross ice streams in West Antarctica that flow over fine-grained glaciomarine sediments, coupling is generally weak and basal motion is confined to sliding of ice over till, or deformation of a very thin (a few centimeters thick) till layer (Engelhardt and Kamb, 1998). Coarse and clast-rich tills are believed to deform in a ductile upper layer (the 'A horizon') only, which overlies consolidated sediments that remain immobile or show signs of brittle deformation (Boulton and Hindmarsh, 1987; Nelson and others, 2005). This proposed mechanism leaves open the question of till origin and bedrock erosion underneath a stationary till.

On Black Rapids Glacier, Alaska, USA, seismic results indicated a locally prevalent, water-saturated till layer several meters thick (Nolan and Echelmeyer, 1999a). In 1997, this was confirmed by drilling and sampling a $7 \mathrm{~m}$ thick till layer under $500 \mathrm{~m}$ of glacier ice, slightly to the north of the center line, where the seismic anomaly had been detected (Truffer and others, 1999). A $5 \mathrm{~m}$ layer of till was also sampled at the center line, where the glacier is $600 \mathrm{~m}$ thick. Inverse modeling shows evidence of seasonal changes in basal stress at the lateral site (Amundson, 2006). In 1997, the upper $2 \mathrm{~m}$ of the till layer at that site were instrumented with three tiltmeters and a pore-water pressure transducer (Truffer and others, 2000; referred to as THE (2000) below). The results were surprising: from measurements and calculations of ice deformation we concluded that $50-70 \%$ of the glacier's annual motion occurred as basal motion. We also concluded that much of this motion occurred at $>2 \mathrm{~m}$ depth below the ice-till interface, because we found no evidence for significant sliding of ice over till or till deformation in the upper $2 \mathrm{~m}$. This was in contrast to published results from other glaciers and conventional wisdom, which restricts basal motion to a thin layer of sediment (e.g. Boulton and Hindmarsh, 1987). Our findings 


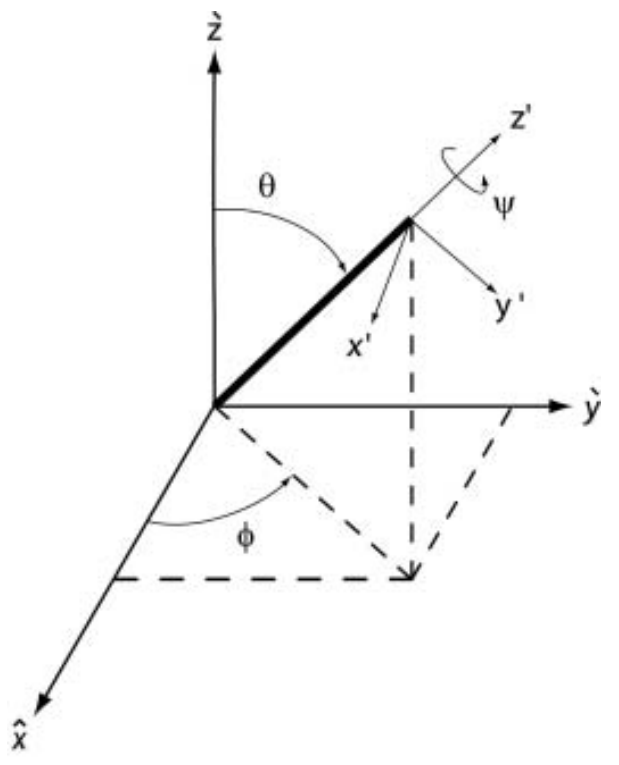

Fig. 1. Geometry of the tilt sensor (adapted from Gudmundsson and others, 1999). A transformation from a map coordinate system $(x, y, z)$, with $x$ horizontal in the flow direction and $z$ vertical up, to a tilt sensor system can be achieved by three rotations $(\phi, \theta, \psi)$, where $\phi$ denotes an azimuth, $\theta$ the tilt from vertical and $\psi$ a rotation around the tilt sensor axis. Dual-axis tiltmeters can only measure changes in $\theta$ and $\psi$, not those of azimuth, $\phi$.

were based on the fact that the tiltmeters did not record a significant amount of deformation and remained connected to the surface for over 400 days via a cable. These results were sufficiently intriguing to merit new measurements with improved methods.

We recognized that the primary challenge for measuring till deformation is insertion of instruments into the subglacial till. Not only is the location of an ice-till interface difficult to determine (if a clear interface exists at all), but often penetration of any instrument is easily stopped in a clast-rich till. In 1997 we had employed a commercial wireline drill to overcome this problem, but the approach was expensive and not deemed practical for future drilling operations. We therefore developed a heavy down-borehole hammer in the hope of penetrating several meters of till. The primary goal of the new project was to develop and test this hammer together with newly developed autonomous subglacial probes. Harrison and others (2004) report on the method; here we present results from a field test.

\section{Field site}

Black Rapids Glacier is a $40 \mathrm{~km}$ long surge-type glacier in the central Alaska Range. It last surged in 1936/37. Moraine patterns indicate a recent surge period of 75-100 years, but currently there are no indications of an impending surge. Since 1973, mass balance, surface velocity and elevation have been measured at least annually at several index sites (Heinrichs and others, 1996). A continuation of these studies shows that the surface elevation in the accumulation area has stopped increasing in the last decade (unpublished data, http://www.gi.alaska.edu/ truffer/BRmonitoring.pdf). Currently, no indications point to an imminent surge. In the 1990s, hydrological (Cochran, 1995; Raymond and others, 1995; Raymond and Nolan, 2000), seismic (Nolan and Echelmeyer, 1999a, b) and radar (Gades, 1998) studies were carried out. In 1996, 1997 and 2002 we conducted borehole studies (Truffer and others, 1999). Here we report on parts of the 2002 drilling program. The location of the 2002 boreholes was identical to that of the 1997 boreholes (in a Eulerian sense). The surface elevation is $\sim 1650$ ma.s.l., which puts the study area into the upper part of the ablation zone, an area characterized by a number of marginal lakes that drain during the ablation season and cause speed-up events.

\section{METHODS}

In May 2002 we field tested the new subglacial hammer. The principle of the hammer follows the design of Blake and others (1992), but the active hammering mass (up to $477 \mathrm{~kg}$ ) is about two orders of magnitude greater. Autonomous wireless instrument packages ('probes') were inserted into the drill rod with a removable anchor attached at the bottom that was designed to stay behind when the drill rod was hammered out. The hammer with the drill rod was then lowered into a hot-water drilled hole and operated via a rope from the surface. Harrison and others (2004) report on the hammer, the probes and the field test in detail. The test can be considered a partial success. We received data from two probes, for up to 1 year after installation, although data recovery was intermittent. Maximum till penetration was just over $2 \mathrm{~m}$ (which was less than we had hoped for). There were no indications for a thinner till layer than the $7 \mathrm{~m}$ found in 1997; surface elevation and ice thickness had changed little in the intervening years.

The probes consisted of a $61 \mathrm{~cm}$ long pressure-sealed tube containing a dual-axis tiltmeter, a pore-water pressure transducer, a microprocessor, a coiled transmitting antenna and a pack of lithium batteries. They transmitted an extremely low-frequency magnetic wave $(\sim 500 \mathrm{~Hz})$ to a receiver that was hanging in the borehole above and was connected to the surface with an electrical cable. We chose this somewhat awkward and slow transmission method because we were confident that it could be used to transmit through several meters of water-saturated till. It is worth noting that transmission of an electromagnetic signal through water-saturated till and temperate ice containing water is a significant problem, a lesson learned by other groups attempting similar work (e.g. Martinez and others, 2004).

The resolution of the tiltmeters was about $0.1^{\circ}$ for the range $0-25^{\circ}$, decreasing to $0.3^{\circ}$ at $70^{\circ}$. Data were digitized before being transmitted to eliminate the risk of adding noise by reading out analog signals through long cables. We used two receivers, $\mathrm{R} 1$ directly above the probes, and $\mathrm{R} 2$ that was $32 \mathrm{~m}$ upstream of the probes. For the first 100 days signals were received exclusively by $\mathrm{R} 1$; after that they were received exclusively by $\mathrm{R} 2$. Some signals were lost due to battery failures at the surface.

Data reception was intermittent. The main problem was considerable clock drift in the probes. The power requirements meant that the receiver could not 'listen' for a signal at all times. When a signal was received, the logger turned on 10 min earlier the next day and listened for a maximum of $20 \mathrm{~min}$. If no signal was found during that time, the receiving data logger was programmed to scan 20 min later the following day, until signals were eventually picked up again. This explains the temporal clustering of the data: once a signal was lost it could take many days before it was picked up again. 


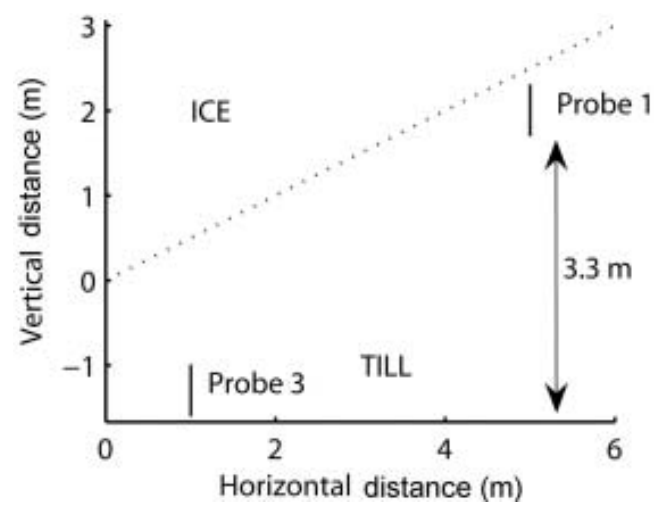

Fig. 2. Sketch of the probe placement (to scale). Signals were received from two probes placed about $4 \mathrm{~m}$ from each other in the cross-flow direction and at different depths. The slope of the ice-till interface is in close agreement with the larger-scale slope obtained from radio-echo sounding. Flow direction is out of the page.

The tilt data were converted to tilt angle $\theta$ and a rotation angle $\psi$, using a coordinate transformation from a map frame to the tilt sensor frame (Fig. 1, adapted from Gudmundsson and others, 1999). The probes did not contain a compass, so the azimuth, $\phi$, could not be resolved. Changes in $\psi$ are sometimes interpreted as changes in azimuth, based on the usually reasonable assumption that a change in azimuth causes an equal change in rotation (e.g. Blake, 1992). There is some ambiguity in this interpretation; nevertheless, any change in rotation indicates a departure from unidirectional simple shear. Here, we estimated strain rates using an assumption of simple shear. A minimum strain rate was calculated from the change in tilt angle only. This is a minimum rate because any mismatch between the azimuth of the probe and the shear direction results in a higher rate. We estimated a 'maximum' tilt rate by calculating strain rates between each data pair, and interpreting changes in rotation as azimuth changes. A true maximum cannot be obtained, because changes in azimuth without changes in rotation or tilt angle would go undetected.

In addition to subglacial measurements, surface position was recorded twice a day for half an hour using GPS (global positioning system) methods. The GPS antenna was fixed to a tripod that was resting on the glacier surface. This was done to avoid problems with excessive antenna heights as the summer progressed. No meaningful vertical velocities could be derived in this way. The GPS data were processed against a local base station, situated about $1.7 \mathrm{~km}$ away on a moraine.

\section{RESULTS}

Two probes were successfully installed in boreholes located $4 \mathrm{~m}$ from each other in a cross-flow direction (Fig. 2). The transverse local ice-bed slope was found to be $30^{\circ}$, which agrees well with the average slope obtained from radio-echo sounding (Gades, 1998). Probe 1 started transmitting on day 137 of 2002 and continued intermittently until day 278 . Probe 3 was installed on day 145 of 2002. During a field visit in spring 2003, after replacing receiver batteries and resetting equipment, several transmissions were picked up from this probe, the last one on day 133 of 2003, almost a year after installation.

Both records show highly correlated variations in tilt angle and rotation around the tiltmeter axis (Fig. 3a and b).
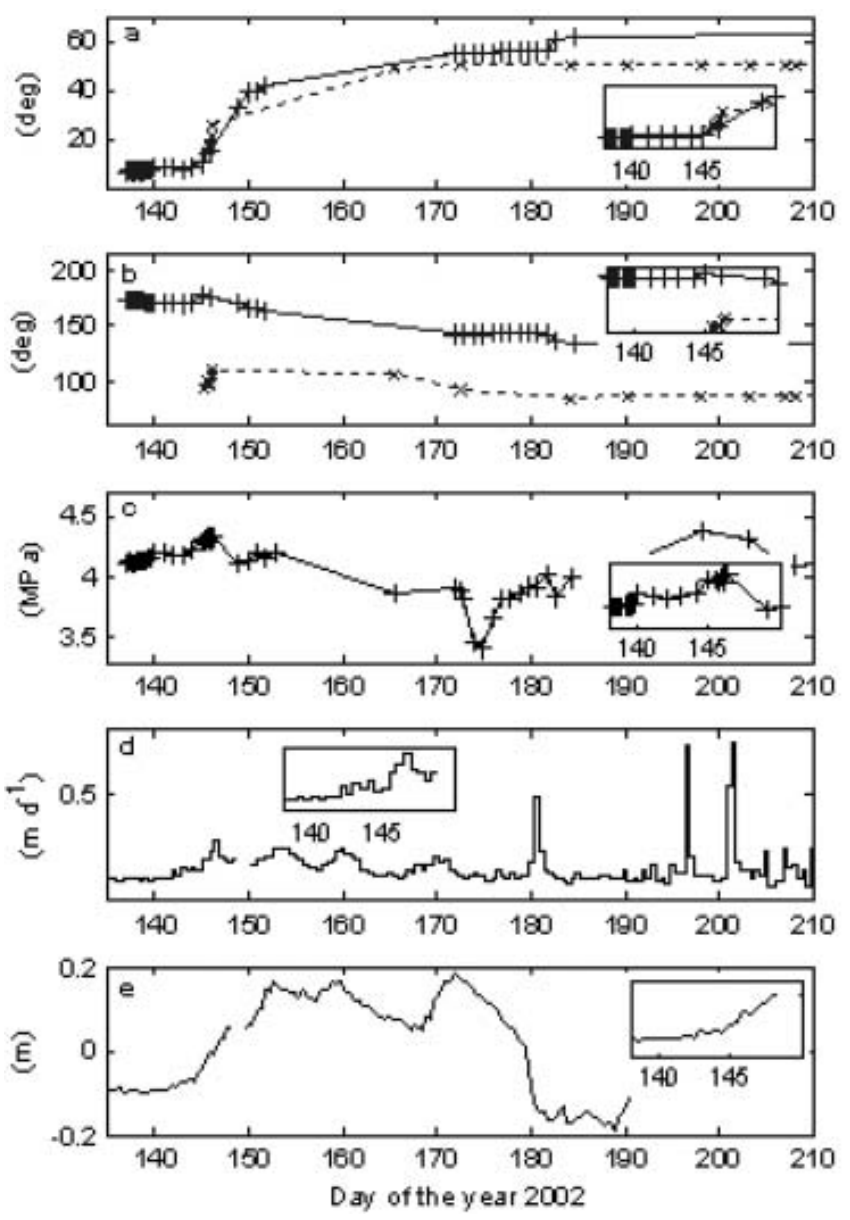

Fig. 3. Summer 2002 measurements. (a) Tilt of probe 1 (solid line, +) and probe 3 (dashed line, $\times$ ). (b) Rotation around tiltmeter axis (probe 1, solid, +; probe 3, dashed, $\times$ ). Changes in tilt angle and rotation rates occur simultaneously. Between days 152 and 165, probe rotation changes by about $30^{\circ}$ without a simultaneous change of tilt. (c) Pore-water pressure record from both probes (see text). (d) Surface speed measured with GPS methods. (e) Surface displacement transverse to the mean flow direction. Positive numbers indicate a departure to the left of the flowline. Insets repeat data between days 138 and 150 .

The records are highly episodic; long periods of quiescence are interrupted by short periods of active deformation. The last part of the probe 3 data is from the following year and that part of the record is not shown. It implies a large change in rotation around the tiltmeter axis. It is possible to reproduce those measurements by rotating the probe through $90^{\circ}$ of tilt and continue 'bottom side up', but this is purely speculative because the large gap in the record does not allow us to resolve the path of the probe. Furthermore, on 3 November 2002 (day 307), a magnitude 7.9 earthquake was caused by the rupture of the Denali Fault, which runs underneath Black Rapids Glacier (Truffer and others, 2002). A fault scarp could be observed on the surface of the glacier in the vicinity of the boreholes, and subsequent GPS measurements showed a displacement of $3.5 \mathrm{~m}$ across the glacier (Hreinsdóttir, 2005). We will therefore not attempt to interpret the last part of the probe 3 record.

The probes also recorded pore-water pressure. Measurements from the two probes were programmed not to coincide, to avoid interference between transmissions. In 


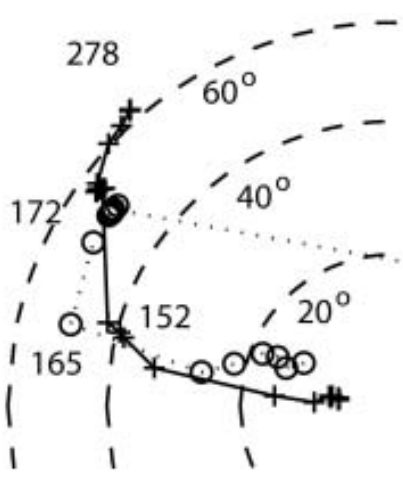

Fig. 4. Trajectory plot of probe 1 (solid line, + , upright labels) and probe 3 (dotted line, $O$, italic labels). The rotation is interpreted as azimuth. The initial azimuth of probe 3 was adjusted so that the initial trajectory roughly coincides with that of probe 1 . Unidirectional shear would produce a straight line in this projection. Both probes initially follow a straight line, but depart sharply between days 165 and 172. The last records from probe 3 were recorded in the following year.

the early days of operation, data were transmitted every 4 hours, and probe 1 and probe 3 data were thus taken within a short period of each other. A comparison of the closest data points (within $45 \mathrm{~min}$ ) shows a difference equivalent to $3.3 \mathrm{~m}$ of hydrostatic pressure, which equals the vertical separation of the pressure ports (Fig. 2). This could imply a high hydraulic conductivity, as a lower conductivity would lead to a delayed response deeper in the till. This had also been inferred from earlier measurements (THE, 2000). We therefore shifted the probe 3 data by $-32 \mathrm{kPa}$ (corresponding to $3.3 \mathrm{~m}$ of water) and combined it with the probe 1 record (Fig. 3c).

Surface position near the borehole was recorded twice daily during summer 2002 and used to derive a velocity record (Fig. 3d). It shows a gradual increase in velocity, starting on day 140, with the first spring event peaking on day 147 . The velocity varies throughout the summer, and is interrupted by sharp motion events, that have been linked to lake drainages in other years (Nolan and Echelmeyer, 1999a; Truffer and others, 2001). These events are accompanied by motion transverse to the mean flowline (Fig. 3e).

\section{DISCUSSION}

\section{Cross-flow tilting}

Dual-axis tilt measurements cannot be interpreted in a unique fashion unless flow proceeds in a well-defined straight flow plane. The measurements yield tilt and rotation around the probe axis. Sometimes this rotation is plausibly interpreted as a change in flow azimuth (Fig. 4). Since the probes are not oriented in the flow direction initially, a simultaneous change in azimuth and tilt is to be expected. However, in our case, both probes showed a clockwise rotation between days 152 and 165, while the tilt angle remained almost constant. Note that the change in rotation is quite significant (Fig. 4). There is small net surface motion to the right of the mean flowline during that period, but this is not a significant event in the surface motion record, and cannot be clearly linked to the tiltmeter record (Fig. 3e). All changes in rotation occur simultaneously with changes in tilt angle (Fig. 3). The change in tilt therefore provides a minimum estimate of till deformation, and the timing of events is not affected by considering variations in tilt only. Any change in rotation, however, indicates that the strain field does not consist of simple shear in a constant direction, and our analysis below is necessarily oversimplified. Note that a full measurement of the strain-rate tensor requires the determination of six independent variables (incompressibility does not hold in till).

The simultaneous changes of tilt and rotation in both probes are quite remarkable and imply a spatial homogeneity in the till deformation on the scale of the probe separation (a few meters). The rotation implies a strain field direction that is non-uniform in time.

\section{Till-deformation events}

The tilt record is characterized by a few discrete events interrupted by longer times of inactivity. The events are highly correlated with motion events recorded at the surface, and most of them are observed at both probes (Fig. 3). On day 140, surface velocity as well as pore-water pressure started increasing (insets, Fig. 3). The first significant spring surface-motion event started on day 140, simultaneously with an increase in pore-water pressure and a tilldeformation event. Till deformation continued through a series of spring surface-motion events, with some indication of a lower deformation rate during times of lower glacier motion. Later in the summer, larger motion events were recorded at the surface; presumably a reaction to the sudden drainage of marginal lakes and supraglacial potholes. The probes do not react strongly to these events. An effect can only be seen at probe 1 during the first large event (day 181), but the till-deformation event only occurs after termination of the day-long motion event. This can be interpreted in the same way as the observations of Iverson and others (2003) who reported reduced ice-till coupling during times of fast motion and increased coupling and therefore till deformation after a motion event. In any case, a fundamental difference is observed in till behavior during the spring speed-up events as compared to the lake-drainage events. The spring speed-up events are triggered from down-glacier, travel upstream and last several days, while the lake drainages happen upstream of the drill site and trigger short-lived motion events of several hours to 1 day duration (Truffer and others, 2001; Nolan, 2003; and unpublished data). It should not be too surprising if the reaction of the till layer is also different for these events.

Mair and others (2003) report observations from three early-season high-velocity events at Haut Glacier d'Arolla, Switzerland. They also observed both styles of increased basal velocities: a decoupling of ice from till and enhanced till deformation.

To assess the total contribution of till deformation to basal motion we first estimated basal motion by subtracting an estimated $0.15 \mathrm{~m} \mathrm{~d}^{-1}$ of internal deformation from the measured surface speed. This value was derived from minimum observed surface speeds and agrees with various modeling estimates (THE, 2000), but our conclusions are not very sensitive to the exact value used. We then estimated till deformation by summing the measurements from probes 1 and 3 only, assuming that all the till deformation is captured by these probes (Fig. 5). Different assumptions about flow direction lead to estimates that are indistinguishable on the scale of this figure. A higher estimate was obtained by extrapolating an average measured strain rate to a $7 \mathrm{~m}$ thick 


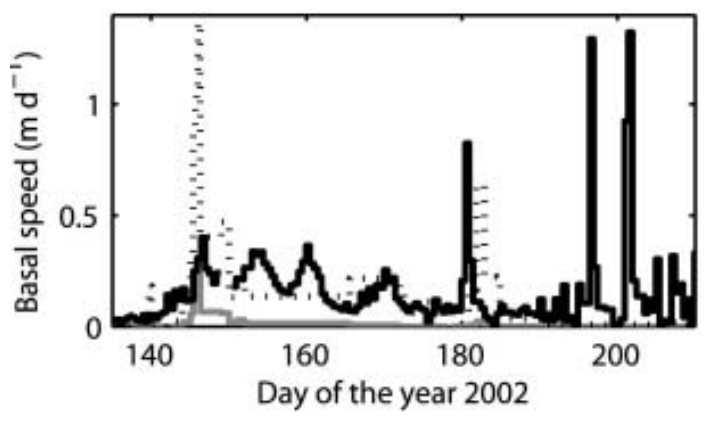

Fig. 5. Estimates of basal motion. Total basal motion is estimated by subtracting $0.15 \mathrm{~m} \mathrm{~d}^{-1}$ from measured surface velocity (black solid line). This is compared to the amount of directly measured deformation (gray solid line), assuming the till only deforms where sampled by the probes; and an extrapolation of measured strain rates to $7 \mathrm{~m}$ of till (dotted line).

till layer. Figure 5 illustrates several things: First, during some events in the early melt season an extrapolation of measured strain rates to a $7 \mathrm{~m}$ thick till layer overestimates basal velocities. Thus the entire layer does not deform uniformly. Second, tilt events reaching several meters below the ice-till interface (at least to the depth of probe 3) can contribute significantly to early-season motion events. Third, the measurements do not indicate a strong contribution to late-season motion events. Strain rates during a week in spring are more than four times larger than the summer average. Between days 170 and 210 a maximum of $40 \%$ of basal motion can be attributed to till deformation, assuming the rates measured at probe 1 apply to $7 \mathrm{~m}$ of till. Since probe 3 does not show significant deformation during this time, this estimate is likely to be high.

While the recorded contribution of till deformation to summer surface motion only seems to be significant in the early melt season, it could nonetheless be quite relevant for bedrock erosion. The presence of thick till layers raises the obvious but unanswered question of how and when they are created. Short but pervasive deformation events could activate the entire till layer and help bedrock erosion. Stresses can be transmitted quite effectively through a granular medium in a process known as 'jamming' (Johnson and others, 2004; personal communication from J.V. Johnson, 2005).

\section{Ice-till sliding}

An indication of sliding of ice over till comes from the reception characteristics of the data signal. As summer progressed, signal reception became increasingly intermittent. In the first 100 days after the installation, only receiver $\mathrm{R} 1$, initially located directly above probe 1 in basal ice, recorded a signal. After that time, receiver R2, originally located $32 \mathrm{~m}$ upstream of probe 1, also in basal ice, started recording signals. The signal strength at the receiver decreases as the third power of the distance between transmitter and receiver, but it also depends on the relative orientations of the two antennas. We calculated the nearfield signal strength (relative to the source) of a dipole field along the axis of the receiver core, assuming a constant tilt rate for the receiver, and using the measured tilt for the transmitter (Fig. 6). We assumed the same azimuth for both transmitter and receiver, but results depend only weakly on this assumption. The relative magnetic susceptibility was
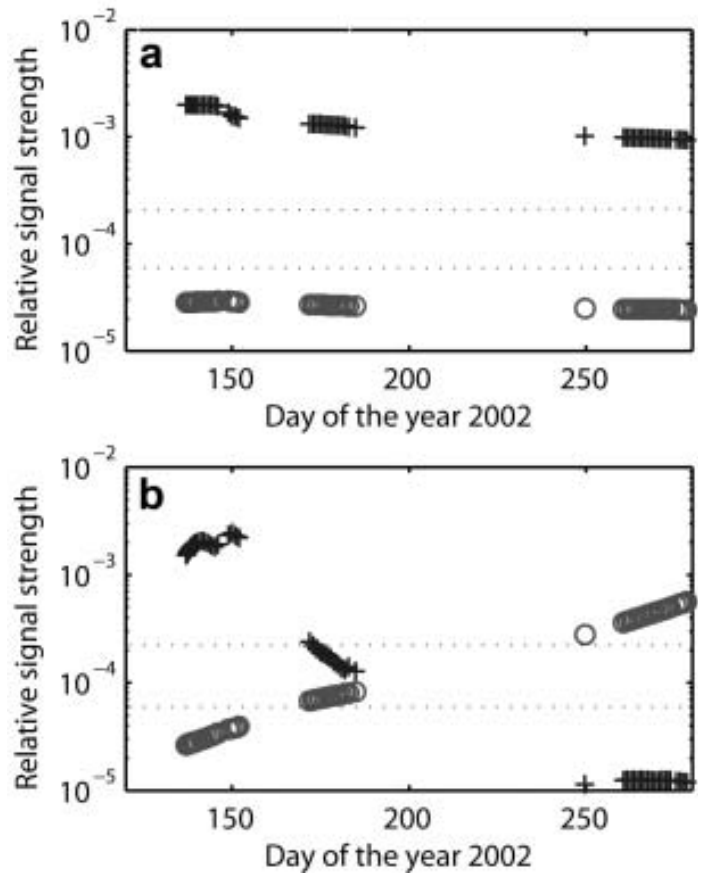

Fig. 6. Calculation of relative signal strength at the two receivers $(\mathrm{R} 1,+; \mathrm{R} 2, \mathrm{O})$ for probe 1 . (a) No ice-till sliding. (b) Ice-till sliding accounts for all estimated basal motion. Dashed lines show a range for the lower detection limit estimated from tests prior to instrument deployment.

assumed to be $\mu=1$, which is reasonable for ice, but is not known for Black Rapids till. We calculated two scenarios: 'no sliding', and 'maximum sliding'. Maximum sliding was assumed to be $0.27 \mathrm{~m} \mathrm{~d}^{-1}$ during summer and $0.12 \mathrm{~m} \mathrm{~d}^{-1}$ during winter (guided by results from Truffer and others, 2001). We know from tests conducted in the vicinity of Fairbanks that the detection limit of the receivers is in the range $7 \times 10^{-5}$ to $2 \times 10^{-4}$ relative signal strength (dotted lines in Fig. 6). The subglacial environment is probably electromagnetically quiet, so the detection limit is likely to be near the lower end of this range. Our analysis shows that under the no-sliding assumption, signal strength remains very high for R1 and below the detection limit for R2 during the entire period (Fig. 6a). However, if R2 is allowed to move downstream, signal strength at R2 starts to exceed that of R1 after about day 190. If the last signal received at R1 is taken as the detection limit, an extrapolation of R2 signal strength (Fig. 6b) indicates that it should exceed this limit after day 217. Because R2 had not received any signals before, it did not turn on at the correct time to pick up a signal on day 217; the closest listening time was about 1 hour off. The receiver automatically scans at different times until it locks into a signal, but it can take up to 10 days to find a lost signal. Unfortunately, on day 221, battery power was lost for R2, and it was only restored on day 249, when we replaced the battery. At that time R2 started picking up signals. After day 279, battery power was lost once again.

These results vary only slightly with different assumptions about flow azimuths and tilt angles. Sliding rates or shallow till deformation of at least two-thirds of the total rate of basal motion are needed to obtain the observed crossover of signal strength. This result applies to the summer season, when these measurements were made. 
This calculation was repeated for probe 3, yielding very similar results. It is difficult to explain this observation with a mechanism other than sliding of ice over till, or till deformation in a thin layer (between probe 1 and the interface).

Another observation lends support to the importance of sliding of ice over till. During a first test of hammering into till, a mechanical problem led to the drill being stuck at $1.5 \mathrm{~m}$ in the till for 4 days (Harrison and others, 2004). When it was finally hammered out, the drill rod was bent by $4^{\circ}$. At the time we assumed that this was a result of prolonged hammering with too much active weight, and subsequently we used smaller weights. In hindsight, however, we have to consider the possibility that the bending was a result of sliding motion. Humphrey and others (1993) reported a similar incident on Columbia Glacier, Alaska.

\section{Comparison with earlier results}

In 1997 a borehole was drilled at the same map location as the two holes discussed here, using a commercial wireline drill rig (Truffer and others, 1999). Discontinuous sediment samples from a $7 \mathrm{~m}$ thick till layer were obtained. After drilling, three $16 \mathrm{~cm}$ long tilt sensors were installed in the borehole, one near the ice-till interface, one at $1 \mathrm{~m}$ and one at $2 \mathrm{~m}$ depth in the till. The tilt sensors were connected to each other and the glacier surface by a signal cable, and a weight was hung below the lowest sensor. Results from this field effort were reported by THE (2000). We concluded:

1. Between $50 \%$ and $70 \%$ of annual glacier motion occurs as basal motion, and most of it at $>2 \mathrm{~m}$ depth below the ice-till interface, either along well-defined shear zones, or as sliding of till over bedrock (or both).

2. Many tilt events were observed at all depths; often they were reversible.

3. The total amount of tilt registered by the tiltmeters did not integrate to a substantial amount of basal motion.

4. The treatment of subglacial till as a viscous material cannot explain the instrument record.

Conclusions 2-4 still hold in light of the 2002/03 results reported here, even though, in contrast to the 1997 measurements, very few small reversible tilting events were observed this time, and the integrated tilt record for the summer accounts for a somewhat larger fraction of basal motion. Both observations could be explained by the longer probes $(61 \mathrm{~cm}$ vs $16 \mathrm{~cm})$ if shear occurs on discrete planes, which would have a higher likelihood of being sampled by the longer instrument.

The older measurement method was subject to higher noise levels. Our new set-up included on-site signal digitization before transmission, which can significantly reduce noise due to signal transmission through a $500 \mathrm{~m}$ long cable. Also, in 1997 we sampled every $20 \mathrm{~min}$, compared with less than once a day in the 2002/03 experiment. The reduced sampling might not record shortlived events.

The first conclusion resulting from our 1997 measurements is at odds with our present discussion about sliding of ice over till. It is difficult, if not impossible, to explain our recent observations without assuming a significant amount of ice-till sliding. The difference from our earlier observations could result from a change in basal conditions since
1997 (temporal change), from small-scale variability in basal motion (spatial inhomogeneity) or from a misinterpretation of earlier results. We will discuss all three possibilities, without reaching a definite conclusion.

Have conditions changed since 1997? Annual observations of the glacier surface elevation in the vicinity of the drill site show an elevation change of $<0.5 \mathrm{~m}$ and no change in surface slope. The annual surface velocity increased from $62 \mathrm{ma}^{-1}$ in $1997 / 98$ to $68 \mathrm{ma}^{-1}$ in 2002/03. Surface velocities can change by over $50 \%$ in 5 years as a consequence of changing rates of basal motion (Heinrichs and others, 1996). The $10 \%$ increase in annual surface velocity between 1997 and 2002 cannot be explained by changing ice deformation. One can only speculate whether the increased basal motion also reflects a change in flow mechanisms, but it is consistent with all our measurements that the increase in basal motion reflects a decrease in icetill coupling.

THE (2000) suggested that basal motion occurred either at the till-bedrock interface (where active erosion would take place, maintaining till balance), or on a series of thrust faults. Some of these faults could intersect the ice-till interface and run along the interface, explaining the discrepancy between our 1997 and 2002 observations. The very similar records of the two separated probes argue against this interpretation.

Let us also re-examine the 1997 no-sliding conclusion. It was based on the fact that after 400 days of measurements the tilt sensors were still recording values within their range. We concluded that ice-till sliding would either have destroyed the signal cable or pulled out the sensors; both would have been recognizable in the signal. The question now is whether it was possible for the tilt sensors to remain in a near-vertical position, while the ice above them was sliding at rates of up to $40 \mathrm{ma}^{-1}$, without the cable being destroyed. To help us answer this we asked the cable manufacturer, Cortland Cable Company, to conduct a test with a short length of similar cable. Their original specification was that the cable would be able to stretch by $10 \%$. In this new test it was found that electric continuity was maintained at a stretch of over $26 \%$, and when the cable finally broke, it did so at a spliced end (personal communication from D. Bentley, Cortland Cable Company, 2004). We estimated $30-45 \mathrm{~m}$ of basal motion during the 400 days lifetime of the 1997 experiment. The stretch experiment shows that this could potentially have been accommodated by cable stretch, if distributed sufficiently over the $500 \mathrm{~m}$ cable. It is therefore conceivable that our earlier interpretation has to be reconsidered, although it still seems very difficult to imagine the signal cable surviving such rough conditions. If nothing else, this problem makes a strong case for the use of autonomous wireless probes.

\section{CONCLUSIONS}

Measured sediment deformation was episodic and strongly related to the first melt-season motion event. The same behavior (tilting and rotating) was recorded by probes situated several meters from each other and at different depths below the ice-till interface. This implies uniformity of till deformation on the scale of several meters. Later in the melt season motion events, presumably initiated by lake or pothole drainages, leave only a weak record (if any) in the tilt measurements. During most times, measured till 
deformation is not significant. This latter observation is in close agreement with results from THE (2000).

The reception characteristics of the signals from the two probes provide strong evidence for ice-till sliding accounting for two-thirds of the inferred basal motion during summer; and basal motion accounts for $50-70 \%$ of the surface motion. Further evidence for ice-till sliding stems from the bending of the drill rod embedded in till. This conclusion is in apparent contrast to THE's (2000) findings. This could be due to a change in basal conditions since 1997. In this time the surface velocity has increased by $10 \%$, with very little change in ice thickness or surface slope. As Black Rapids Glacier is surge-type, an evolution of the basal motion regime over decadal time-scales is a definite possibility that cannot be discounted a priori. Decadal-scale variations of surface velocity exceed $50 \%$ and are due to changes in basal motion (Heinrichs and others, 1996). A reexamination of our 1997 results shows that it is conceivable, but unlikely, that we missed a significant amount of ice-till sliding in our earlier measurements.

This leads us to the following picture of seasonal motion and till deformation during 2002: During winter, till deformation is not significant (see late-season results (days 200300), Fig. 3). In spring a speed-up event is initiated downglacier. At this time, the ice is coupled to the underlying till, and till deformation occurs to several meters depth and appears spatially uniform. As summer progresses, new water reaches the base. Much larger speed-up events (day 180 and later) are enabled by decoupling of the bed from the till layer. Relatively weak till deformation does occur, but only after the speed-up event, presumably when coupling between ice and till is re-established. During the measurement period, sliding of ice over till, or deformation of a thin till layer $(<20 \mathrm{~cm})$ is significant and indications are that this sliding amounts to at least two-thirds of total basal motion.

One of the more interesting observations is the seasonality of the till processes. Most of the deformation takes place early in the melt season and is constant with depth below the interface (at least to the depth of our observations). This bears on a key issue not previously addressed in the analysis of borehole observations: the erosion of the bed and the consequent replenishment of till. Whatever the details, the observations suggest that these processes are highly seasonal, and possibly take place within a short fraction of the year. One should keep in mind, however, that in the case of Black Rapids Glacier, erosion during surging is likely to be an important process, as suggested by observations of Variegated Glacier during surge (Humphrey and Raymond, 1994).

The work described in this paper was performed primarily as 'proof of concept' for a new drilling technology and new instrument design. As such, it did not employ a comprehensive set of instruments, although it is clear that conclusions about basal motion require a combined instrument approach. Possibly our understanding of the required measurements and their spatial density will evolve in parallel with our understanding of the basal processes themselves. A good example is the issue of spatial coherence of the motion; at our site till deformation seems to be coherent on the scale of $4 \mathrm{~m}$ (the separation of the probes). However, coherence on the scale of hundreds of meters (ice thickness) seems unlikely because of the weakness of the correlation between the direction of tilting and the transverse component of surface motion.

\section{ACKNOWLEDGEMENTS}

K. Echelmeyer, D. Pomraning, K. Abnett and R. Ruhkick were instrumental in planning and carrying out this work. We would also like to thank the many helpers in the field and VECO Polar Resources for logistical support. This work was supported by grants OPP-0085085 and OPP-0115819 from the US National Science Foundation. J. Glen acted as Scientific Editor and I. Willis and Th. Thorsteinsson carefully reviewed the manuscript.

\section{REFERENCES}

Amundson, J. 2006. Evidence for stress redistribution beneath Black Rapids Glacier, Alaska. (MS thesis, University of Alaska Fairbanks.)

Blake, E.W. 1992. The deforming bed beneath a surge-type glacier: measurement of mechanical and electrical properties. (PhD thesis, University of British Columbia.)

Blake, E., G.K.C. Clarke and M.C. Gérin. 1992. Tools for examining subglacial bed deformation. J. Glaciol., 38(130), 388-396.

Boulton, G.S. and R.C.A. Hindmarsh. 1987. Sediment deformation beneath glaciers: rheology and geological consequences. J. Geophys. Res., 92(B9), 9059-9082.

Cochran, O.D. 1995. The subglacial hydraulics of the surge-type Black Rapids Glacier, Alaska: a schematic model. (MSc thesis, University of Alaska Fairbanks.)

Engelhardt, H. and B. Kamb. 1998. Basal sliding of Ice Stream B, West Antarctica. J. Glaciol., 44(147), 223-230.

Fischer, U.H. and G.K.C. Clarke. 2001. Review of subglacial hydromechanical coupling: Trapridge Glacier, Yukon Territory, Canada. Quat. Int., 86, 29-43.

Fischer, U.H., G.K.C. Clarke and H. Blatter. 1999. Evidence for temporally varying "sticky spots" at the base of Trapridge Glacier, Yukon Territory, Canada. J. Glaciol., 45(150), 352-360.

Gades, A.M. 1998. Spatial and temporal variations of basal conditions beneath glaciers and ice sheets inferred from radio echo soundings. (PhD thesis, University of Washington.)

Gudmundsson, G.H., A. Bauder, M. Lüthi, U.H. Fischer and M. Funk. 1999. Estimating rates of basal motion and internal ice deformation from continuous tilt measurements. Ann. Glaciol., 28, 247-252.

Harrison, W.D., M. Truffer, K.A. Echelmeyer, D.A. Pomraning, K.A. Abnett and R.H. Ruhkick. 2004. Probing the till beneath Black Rapids Glacier, Alaska. J. Glaciol., 50(171), 608-614.

Heinrichs, T.A., L.R. Mayo, K.A. Echelmeyer and W.D. Harrison. 1996. Quiescent-phase evolution of a surge-type glacier: Black Rapids Glacier, Alaska, U.S.A. J. Glaciol., 42(140), 110-122.

Hreinsdóttir, S. 2005. Coseismic deformation of the $2001 \mathrm{El}$ Salvador and 2002 Denali Fault earthquakes from GPS geodetic measurements. (PhD thesis, University of Alaska Fairbanks.)

Humphrey, N.F. and C.F. Raymond. 1994. Hydrology, erosion and sediment production in a surging glacier: Variegated Glacier, Alaska, 1982-83. J. Glaciol., 40(136), 539-552.

Humphrey, N., B. Kamb, M. Fahnestock and H. Engelhardt. 1993. Characteristics of the bed of the lower Columbia Glacier, Alaska. J. Geophys. Res., 98(B1), 837-846.

Iverson, N.R. 1999. Coupling between a glacier and a soft bed. II. Model results. J. Glaciol., 45(149), 41-53.

Iverson, N.R., B. Hanson, R.LeB. Hooke and P. Jansson. 1995. Flow mechanism of glaciers on soft beds. Science, 267(5194), 80-81.

Iverson, N.R., T.S. Hooyer and R.W. Baker. 1998. Ring-shear studies of till deformation: Coulomb-plastic behavior and distributed strain in glacier beds. J. Glaciol., 44(148), 634-642.

Iverson, N.R. and 6 others. 2003. Effects of basal debris on glacier flow. Science, 301(5629), 81-84.

Johnson, J.V., P.R. Prescott and T.J. Hughes. 2004. Ice dynamics preceding catastrophic disintegration of the floating part of Jakobshavn Isbræ. J. Glaciol., 50(171), 492-504. 
Kamb, B. 1987. Glacier surge mechanism based on linked cavity configuration of the basal water conduit system. J. Geophys. Res., 92(B9), 9083-9100.

Mair, D., I. Willis, U.H. Fischer, B. Hubbard, P. Nienow and A. Hubbard. 2003. Hydrological controls on patterns of surface, internal and basal motion during three 'spring events': Haut Glacier d'Arolla, Switzerland. J. Glaciol., 49(167), 555-567.

Martinez, K., J.K. Hart and R. Ong. 2004. Environmental sensor networks. IEEE Computer, 37(8), 50-56.

Nelson, A., I. Willis and C. O'Cofaigh. 2005. Evidence for subglacial sediment deformation and sliding beneath the surge-type glacier, Brúarjökull, Iceland. Ann. Glaciol., 42, $14-22$.

Nolan, M. 2003. The 'Galloping Glacier' trots: decadal-scale speed oscillations within the quiescent phase. Ann. Glaciol., 36, 7-13.

Nolan, M. and K. Echelmeyer. 1999a. Seismic detection of transient changes beneath Black Rapids Glacier, Alaska, U.S.A.: I. Techniques and observations. J. Glaciol., 45(149), 119-131.

Nolan, M. and K. Echelmeyer. 1999b. Seismic detection of transient changes beneath Black Rapids Glacier, Alaska, U.S.A.: II. Basal morphology and processes. J. Glaciol., 45(149), 132-146.

Raymond, C.F. and M. Nolan. 2000. Drainage of a glacial lake through an ice spillway. In Debris-Covered Glaciers. Wallingford, Oxon. International Association of Hydrological Sciences, 199-207. (IAHS publication 264.)

Raymond, C.F., R.J. Benedict, W.D. Harrison, K.A. Echelmeyer and M. Sturm. 1995. Hydrological discharges and motion of
Fels and Black Rapids Glaciers, Alaska, U.S.A.: implications for the structure of their drainage systems. J. Glaciol., 41(138), 290-304.

Sturm, M. and D.M. Cosgrove. 1990. Correspondence. An unusual jökulhlaup involving potholes on Black Rapids Glacier, Alaska Range, Alaska, U.S.A. J. Glaciol., 36(122), 125-126.

Thorsteinsson, T. and C.F. Raymond. 2000. Sliding versus till deformation in the fast motion of an ice stream over a viscous till. J. Glaciol., 46(155), 633-640.

Truffer, M., R.J. Motyka, W.D. Harrison, K.A. Echelmeyer, B. Fisk and S. Tulaczyk. 1999. Subglacial drilling at Black Rapids Glacier, Alaska, U.S.A.: drilling method and sample descriptions. J. Glaciol., 45(151), 495-505.

Truffer, M., W.D. Harrison and K.A. Echelmeyer. 2000. Glacier motion dominated by processes deep in underlying till. J. Glaciol., 46(153), 213-221.

Truffer, M., K.A. Echelmeyer and W.D. Harrison. 2001. Implications of till deformation on glacier dynamics. J. Glaciol., 47(156), 123-134.

Truffer, M., P. Craw, D. Trabant and R. March. 2002. Effects of the M7.9 Denali Fault Earthquake on glaciers in the Alaska Range. EOS Trans. AGU, 83(47). Abstract S72F-1334.

Tulaczyk, S. 1999. Ice sliding over weak, fine-grained tills: dependence of ice-till interactions on till granulometry. In Mickelson, D. M. and J.W. Attig, eds. Glacial processes: past and present. Boulder, CO, Geological Society of America, 159-177. (Special Paper 337.)

MS received 2 August 2005 and accepted in revised form 15 March 2006 